\title{
Suriyeli Kadın Sığınmacılar ve Yoksulluk: Malatya Örneği
}

\author{
Syrian Female Refugees and Poverty: The Case of Malatya
}

\author{
Canan Coşkun ${ }^{1}$
}

Öz

Curiyede 2011 yılının Mart ayından itibaren başlayan şiddet, insan hakları ihlalleri, $\checkmark$ iç savaş, küresel güçlerin müdahalesi ya da diğer risklerden dolay1 10 milyondan fazla Suriyeliyi zorunlu kitlesel bir göç hareketine zorlamış ve bu durum insanî bir trajediye dönüşmüştür. Suriye'deki iç savaş hem Suriyeliler 'in kendi evlerini, yurtlarını terk etmelerine sebep olmuş hem de küresel çapta bir sığınmacı (mülteci) sorununun doğmasına sebep olmuştur. Türkiye 29 Nisan 2011'de Suriyeli sığınmacıları (mültecileri) kabul etmeye başladı ve Türkiye sığınmacılar için “açık kapı politikası” nın geçerli olacağını duyurdu.

Türkiye sayıları önemli ölçüde artmış olmasına rağmen Suriyeli sığınmacıları kabul etmeye devam etmektedir. Ekim 2015’e kadar Birleşmiş Milletler Mülteciler Yüksek Komiserliği (UNHRC) Türkiye'de 2 milyondan fazla kayıtlı Suriyeli olduğunu bildirmiştir. Sığınmacıların yaklaşık yüzde 80'ini kadın ve çocuklar oluşturmaktadır. Ayrıca Türkiye'de kırk bin Suriyeli bebek doğmuştur. Bu göç dalgası Türkiye başta olmak üzere Suriye’ye komşu olan birçok ülkeyi demografik, ekonomik, kültürel, sosyal ve siyasal yapısını önemli ölçüde etkilemiştir. Göç fizikî mekân değişimi gibi dar bir değişim algısının ötesinde sosyo-ekonomik, sosyal adaptasyon, sosyal bütünleşme, dil ve yaşam tarzı, kültürel, ideolojik, politik sistemin değişikliğini içermektedir. Bu makale Türkiye Malatya’da yaşayan Suriyeli kadın sığınmacıların gündelik hayat deneyimlerini Pierre Bourdieu'nun sosyolojik kavramları (Alan -Habitus- Sermaye, Kültürel Sermaye, Strateji) ile incelemektedir. Örneklem olarak hem Malatyada yaşayan Suriyeliler hem de Malatya Beydağı Konaklama/Misafirhane Tesisi (MABEK)'nde yaşayan Suriyeli sı̆̆ınmacıların katılımlı bir gözlem metodu ve doküman incelemeleriyle açıklanmaya çalışılmıştır. Yerleşik bir kültürün olduğu bir topluma kısa bir sürede aniden kalabalık bir göçmen kitlesinin gelmesi gündelik hayatı nasıl etkilemektedir?

1 İnönü Üniversitesi Sosyal Bilimler Enstitüsü Sosyoloji Anabilim Dalı Doktora Öğrencisi ve Milli Eğitim Bakanlığı’nda Öğretmen

Başvuru: 1 Aralık 2016

Kabul: 10 cak 2016

DOI: 10.21798/kadem.2017225031
Copyright (c) 2016 · KADEM Kadın ve Demokrasi Derneği

kadinarastirmalari.kadem.org.tr

ISSN 2149-6374 · Aralık 2016 · 2(2) · 88-105 
Sığınmacılar yabancı oldukları şehirde yaşama tutunmak için neler yapmaktadırlar? Son olarak bu yazı ilişkisel sosyoloji diye adlandırılan ilişkisel bakış açısı aracılığıyla Suriyeli kadın sığınmacılar ve yoksulluk arasındaki ilişkiyi analiz eder.

Anahtar Kelimeler: Uluslararası göç, Zorunlu göç, Mülteci, Sığınmacı, Misafir, Ev sahibi, Suriyeli kadın Sığınmacılar, Alan- Habitus- Sermaye, Kültürel sermaye, Strateji, İlişkisel Sosyoloji, Yoksulluk

\section{Abstract}

Wore than 10 million people have fled from Syria because of severe human rights 1 abuses, civil war or other risks, in their own country since the start of the conflict in 2011. The civil war in Syria has displaced vast numbers of Syrians from their homes and communities. Turkey started to accept Syrian refugees on April 29. 2011. Turkey then announced that it would apply an "open door policy" for these refugees. Turkey has continued to accept Syrian refugees even though their population has dramatically increased. By October 2015, The United Nations High Commission on Refugees (UNHRC) reported that there were more than 2 million Syrians registered in Turkey. About 80 percent of the refugees are women and children. Forty thousand Syrian babies were born in Turkey and increasing.

What is more, this article explores the experience of Syrian female refugees who are living in Malatya, Turkey through (field, habitus, capital, cultural capital ) the sociological conceptual tools of Pierre Bourdieu. Finally, this paper presents and analyzes the relation between poverty and Syrian female refugees through 'relational perspective' so-called 'relational sociology'.

Key Words: Migration, International Migration, Forced Migration, Refugee, Guest, Host, Syrian Female Refugees, Field- Habitus- Capital, Cultural Capital, Relational Sociology(RS), Poverty 
Söyleyin dağlara rüzgârlar yurdundan sürgün çocuklara Düşmesin kimse yılginlı̆a, geçit vardır yarınlara Göç yolları göründü bize, görünür elbet göç yolları Bir gün gelir döner tersine dönülür elbet En büyük silah umut etmek, yadigâr kalsin size Yol verin kanatl atlara, sürgünden dönen çocuklara Ateşler yakın doruklarda, geçit vardır yarınlara Dağllsak da göç yollarında, yarın bizim bütün dünya.

Murathan Mungan/Göç Yolları

\section{Giriş}

Rab, Kâbil'e Hâbil'in nerede olduğunu sorduğunda, Kâbil öfkeli bir biçimde bir başka soruyla yanıt verir: "Ben kardeşimin bekçisi miyim?" Kâbil'in yanıtı içten ve samimidir ancak bu yanıtta etik eksiktir. Sadece ontoloji vardır: "Ben benim ve o da o. Biz ontolojik olarak ayrı varlıklarız" (Levinas, 2003, s. 248). "Kardeşimin bekçisi miyim?" sorusundaki sorumluluğun reddine benzer şekilde bugün birçok kişi için ötekinden-başkasından, komşusundan, mülteciden, sığınmacıdan, yabancıdan, göçmenden, kadından, yoksuldan, işsizden sorumlu olmak tahammül edilemez görülmektedir. Bu tahammülsüzlüğün önemli kaynaklarından biri Batı düşüncesinin bir çeşit "ötekileştirme" aracıllğıyla kendini var etmesidir. "Biz" ve "onlar" ayrımı neticesinde oluşan "öteki” üzerinden kendini inşa eden Batı, insanının tavır alış ve tutumlarını da bu yönde etkilemektedir. Kendi ihtiyaçları doğrultusunda göç uzun yıllar boyunca Batı için tatmin ve mutluluk kaynağ iken artık şimdilerde istikrarsızlık ve güvensizlik kaynağı olarak görülüp algılanmaktadır. Bu bakış açısındaki değişim Batı’nın pragmatizmini ve yabancının Batı tarafından aslında nasıl algılandığını yansıtmaktadır. Bu olumsuz tavra rağmen bugün göç olgusu ve sığınmacılar Batı’nın bir gerçekliği haline gelmiştir.

Türkiye ise Suriye'den gelen göçlere karşılık Batı’nın aksine bir politika izlemektedir ve Suriyeli sığınmacıları kabul etmeye devam etmektedir. Dolayısıyla artık Türkiye'de göç ve mülteciler gündelik yaşam pratiklerini etkileme gücüne sahip toplumsal bir olgudur. Bu çalışma Türkiyedeki Suriyeli sığınmacıların toplumsal hayattaki yeri ve gündelik hayatları mercek altına alınacaktır. Böylece gündelik hayatın rutin, alışıla geldik, tanıdık, tekrar edilen nitelikte olan ve fark edilemeyen yönlerine ayna tutmak amaçlanmaktadır. Dolayısıyla "Suriyeli Kadın Sığınmacılar ve Yoksulluk: Malatya Örneği” adlı çalışmamız ile sığınmacıların mevcut sorunların kaynağı olarak algılanmasını ortadan kaldırmak ve Malatya iline göç eden kadın sığınmacıların göç sonrasında 
karşılaştıkları yoksunluklarla nasıl başa çıktıklarını açığa çıkarmak hedeflenmektedir. $\mathrm{Bu}$ çalışmada hem Malatya ilinde hem de bir konteyner kent olan Malatya Beydağ Konaklama Tesislerinde (MABEK) yaşayan sığınmacıların katılımlı gözlem tekniği ve doküman incelemelerinden elde edilen veriler kullanılarak göç olgusu Suriyeli sığınmacı kadınlar ve yoksulluk açısından ele alınmıştır.

\section{Günümüz Modern Dünyasında Sığınmacılar: Suriyeli Sığınmacıların Türkiye’ye Geliş Süreci}

Günümüz dünyası modern bir dünya olarak tanımlanmaktadır. Peki, modern olmak nedir? Günümüz toplumunu bizden daha önceki insan toplumlarından daha modern kılan özellik ya da özellikler nelerdir? Bauman moderniteyi; bahçıvanlık metaforuyla açıklamaktadır. Nasıl ki bahçıvan bahçeyi zararlı otlardan arındırarak, çiçekleri budayarak düzlerse modern uygarlık aynı bahçıvanın yaptığı gibi toplumda benzer şekilde farklı olanın ayrık olana tahammül edememesi, dışlaması, reddetmesi, yok etmesi yani yabancıyı bir düşman olarak görmesi ve holokost (soykırım) yaptığını dile getirmiştir (Bauman, 2003, s. 65-75). Bu tahammülsüzlüğün bir yansıması olarak modernliğin temsilcisi Batı toplumunda ötekine tahammül etmenin tam zıddı olan soykırımlar, etnik temizlikler ortaya çıkmaktadır. Ancak aynı zamanda tahakkümünü ve düzleştirici etkisini daha kabul edilebilir kılmak için dili bir araç olarak kullanmaktan da kaçınmamaktadır. Örneğin etnik temizlik kavramına baktı̆̆ımızda olumlu, güzel, kabul edilebilir bir kavram olan "temizlik" kavramının kullanımı ile "ötekine” yapılan soykırımın meşru ve makul gösterilmeye çalışıldığı görülmektedir. Burada insanî ilişkiler, bir sorumluluk ve ahlâkîlik temelinde değil değişim ve dönüşüm çerçevesinde (sorumluluğun ve ahlâkî davranışın bir fiyatının olup olmadığı hesap edilerek) tekrarlaniyorsa hem moderniteyi hem de modern refah toplumunu bir sanık sandalyesine alıp sorgulamamız gerektiğini gösterir. "Ben fakirleri, göçmenleri, sığınmacıları doyurmak ya da barındırmak zorunda mıyım?" sorusu modern refah toplumlarında sıkça karşılaşılan bir yakınmadır. Bauman bu soruyu şöyle cevaplar: "Elbette ben kabul etsem de etmesem de kardeşimin bekçisiyim ve kardeşimden sorumluyum. Kardeşimin iyiliği benim ne yaptığıma ya da neyi yapmaktan geri durduğuma bağlıdır. Ben ahlâklı biri olduğumdan dolayı bana bağımlı olduğunun farkında olarak sorumluluğumun bilincinde olmalıyım. Niçin bunu yapmam gerektiğine dair sayısız nedenlerim vardır; ancak sorumluluğumu reddedersem ne kadar ahlâklı olabilirim ki?"(Bauman, 2003, s. 100-101).

Bu bağlamda Suriye’den Türkiye’ye yoğun nüfus akışıyla ortaya çıkan Suriyeli s1ğınmacılar sorununa baktığımızda bu sorunun sadece Suriyelileri ilgilendirmediği görülmektedir. Toplumsal, ekonomik ve politik yönleriyle etkili sonuçlar doğuran Suriye'den gelen "zorunlu, kitlesel, düzensiz dış göç”2 Türkiye’nin tüm olanaklarıyla üstesinden gelmeye çalıştığı önemli küresel bir sorundur. Günümüzde Türkiye’de

2 Ülkesinde can ve mal güvenlikleri bulunmayan, her an ölümle karşı karşıya yaşamak durumunda olan ve bu duruma katlanamayarak başka bir ülkeye toplu olarak göç eden Suriyeliler’in durumunu göç tanımlamaları ışı̆̆ında zorunlu, kitlesel dış göç olarak adlandırabiliriz. 
bulunan sığınmacı sayısının 2 milyona ulaştığı bilinirken, bu sayının nerede son bulacağ 1 ise henüz kestirilememektedir. ${ }^{3}$ Suriye'de 2011'de Mart ayında başlayan ve hâlâ devam eden iç savaş, şiddet, zulüm, toplumsal tahammülsüzlük, toplumsal kargaşa ve karışıklıklar neticesiyle milyonlarca Suriyelinin Türkiye başta olmak üzere komşu ülkelere zorunlu, kitlesel, düzensiz dış göç etmesine sebep olmuştur. Suriye'de yaşa-

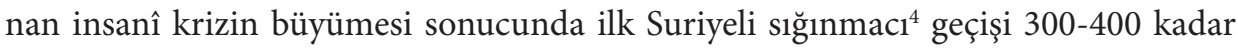
Suriyeli vatandaşın 29 Nisan 2011 tarihinde Hatay ili Yayladağ ilçesindeki Cilvegözü sınır kapısına doğru hareketlenmesiyle başlamıştır. "Açık kapı politikası" çerçevesinde Türkiye’ye giriş yapan ilk göç kafilesiyle birlikte Suriyeli sığınmacılar ile tanışan Türkiye, savaş mağduru bu sığınmacıları "misafir"6 olarak tanımlamıştır. Türkiye'de 10 şehirde kurulan 25 geçici "Barınma Merkezi”" nde 258 bin 572 Suriyeli sığınmacıya

3 Birleşmiş Milletler Mülteciler Yüksek Komiserliğinnin (BMMYK-UNHCR) son raporuna göre 2015 yllının sonuna kadar yüzde ellisinden fazlası kadın ve çocuk olan 2 milyondan fazla kayıtlı, kayıt aşamasında olan Suriyeli mülteci Türkiye’ye girmiștir. Ayrıca Türkiye'de doğan Suriyeli bebeklerin sayısı da 40 bin civarı kadar olduğu tahmin edilmektedir. Haziran 2015 verilerine göre 4 milyon 13 bin Suriyeli mülteci konumundadır. Bunlardan 1 milyon 805 bin 255'i Türkiye'de; 1.191.451'i Lübnan'da; 627. 295'i Ürdün'de; 246.836’sı Irak'ta; 133.619’u Misır'da ve az sayıda da diğer ülkelerde yaşamlarını sürdürmektedir. Birleşmiş Milletler Mülteciler Yüksek Komiserliği ülkelerin göç politikalarını düzenleyen ve yöneten bir kurumdur. Adından da anlaşıldığı gibi güvenlikle ilgilidir. Komiserlik teriminin kökenine bakıldığında güvenlikle ilişkili bir terminolojiyi temsil etmektedir. Dolayısıyla mültecilerin sorunlarına ilişkin köklü çözümler sunma imkânı çok azdır. Çözüm için ekonomik, siyasal, toplumsal, hukuksal ve sosyal değişim ve dönüşümler çerçevesinde iyileşmelerin yapılması gerekir.

4 Mülteci - sığınmacı ve geçici korunma statüsü altındaki Suriyeliler’i ifade etmektedir. Her mülteci göçmendir fakat her göçmen mülteci değildir. Birleşmiş Milletler Mülteciler Yüksek Komiserliği’nin (BMMYK-UNHCR) Birleşmiş Milletler 1951 yılında Cenevre’de yapılan bir toplantı sonrasında "mülteci” kavramını şöyle tanımlanır: 1 Ocak 1951'den önce meydana gelen olaylar sonucunda ve irk1, dini, tabiiyeti belli bir toplumsal gruba mensubiyeti veya siyasî düşünceleri yüzünden, zulme uğrayacağından haklı sebeplerle korktuğu için vatandaşı olduğu ülkenin dışında bulunan ve bu ülkenin korumasından yararlanamayan ya da söz konusu korku nedeniyle yararlanmak istemeyen yahut tabiiyeti yoksa ve bu tür olaylar sonucu önceden yaşadığı ikamet ülkesinin dişında bulunan, oraya dönemeyen veya söz konusu korku nedeniyle dönmek istemeyen kişidir. Sığınmacı ise; ırkı, dini, milliyeti, tercihleri, toplumsal bir gruba üyeliği veya siyasî nedenlerle baskıya uğrama ihtimali olan, kendi ülkesi dışında bulunan ve vatandaşı olduğu ülkenin himayesinden istifade edemeyen, istifade etmek istemeyen, ülkesi dışında bulunuyorsa ülkesine dönmeyen veya dönmek istemeyen yabancıdır. Yani mülteci hukuken statüsü kabul edilmiş bir yabancıyı ifade ederken, sığınmacı mültecilik statüsü incelenen ve bu sebeple kendisine geçici koruma sağlayan kişiyi ifade etmektedir.

5 T.C. İçişleri Bakanlığı Göç İdaresi Genel Müdürlüğü Yayınları, Yayın No:4. Aralık 2013. Ankara

61951 tarihli Mültecilerin Hukuki Durumuna Dair Cenevre Sözleşmesi’nde imzası bulunan Türkiye, coğrafi sınırlama ilkesi dolayısıyla Avrupa dışından gelen sığınmacılara mültecilik statüsü verememektedir. Mültecilerin haklarının Birleşmiş Milletler'in 1967 protokolüyle düzenlenmiştir. Türkiye ise 1967 protokolünü çekinceli olarak kabul etmiş, sözleşmesinin birinci maddesine çekince koyarak coğrafi sınırlamada bulunmuştur. Mevzuata göre mülteci Avrupa menşeili bireyleri kapsamaktadır. Uluslararası hukukta "misafir" tanımlamasının karşllığı bulunmamasından dolayı Nisan 2012'de yayımlanan genelge ile Suriyeliler'e "geçici koruma" statüsü verilmiştir. 2014 tarih ve 6458 sayılı "Yabancılar ve uluslararası Koruma Kanunu”nun "Geçici Koruma" başlıklı 91. maddesi; "ülkesinden ayrılmaya zorlanmış, ayrıldığı ülkeye geri dönemeyen, acil ve geçici koruma bulmak amacıyla kitlesel olarak sınılarımıza gelen ve sınırlarımızı geçen yabancılara geçici koruma sağlanabilir. Diyerek geçici korumaya yasal dayanak oluşturmuş ve geçici korumanın ayrıntılarının Bakanlar Kurulu tarafından çıarılacak yönetmelikle düzenleneceğini belirtmiştir. 6458 sayılı kanunun yukarıda belirtilen maddesine dayanarak çıkarılan "Geçici Koruma Yönetmeliği” 22 Ekim 2014 tarihinde Resmi Gazetede yayımlanarak yürürlüğe girmiştir. Yönetmelik ile Türkiye, Suriye uyruklu yabancılara; açı sınır politikası ile ülke topraklarına koşulsuz kabul; geri göndermeme ilkesinin istisnasız uygulanması, ülkeye kaçak giriş nedeniyle cezalandırılmama ve gelen kişilerin temel ihtiyaçlarının karşılanması hususlarını garanti ederek "geçici koruma" sağlanmıştır. Suriyeliler’e sağlanmış olan bu geçici korunmanın sonlandırılmasına ise Bakanlar Kurulu yetkili kılınmıştır.

7 Barınma Merkezinde (diğer isimleriyle Kamp, misafirhane, çadırkent ya da konteynerkent) kalan Suriyeliler'in eğitimden sağlığa, gıdadan barınmaya kadar her türlü ihtiyaçları barınma merkezinde karşılanmaktadır. 
ev sahipliği yapmaktadır. Göç eden Suriyeliler 'in \%85'i ise kamp dışında yaşadığı bilinmektedir. 2011 - 2016 tarihleri arasında yani beş yılda Türkiye’ye göç eden Suriyeli sığınmacıların sayısının giderek $\operatorname{artması}^{8}$ ve misafirlik sürelerinin uzaması, Türkiye’yi adeta bir mülteci ülkesi konumuna taşımıştır. Suriyeli sı̆̆ınmacıların giderek artan sayıları ile birlikte, misafirlik sürelerinin belirsizliği Türkiye açısından çözüm gerektiren yeni sorunlara kaynaklık etmektedir. Söz konusu sorunlar, Türkiye'nin uluslararası boyutta yeterli ekonomik destekten yoksun olması nedeniyle ${ }^{9}$, başta imkânları zorlayan ekonomik sorunlar olmak üzere, toplumsal, kültürel ve insanî boyuttaki sorunlar şeklinde kategorize edilebilir. Bugün, göçün başladığı ilk dönemlere kıyasla, göçün ekonomik, toplumsal ve kültürel sonuçları daha kapsamlı boyutlara ulaşmış durumdadır. Göçün başladığı ilk aylarda sığınmacı sayısının daha az olması ve Suriye'deki çatışmalara karşı duyarlılığın daha canlı olması gibi sebeplerle mevcut kaynaklarla ihtiyaçların üstesinden gelinebilmiştir. Ancak geçen zaman içerisinde sığınmacıların beraberlerinde getirebildikleri maddî birikimlerinin tükenmesi ve sayılarıyla birlikte ihtiyaçların da artması, bugün hem maddî hem de manevî açıdan devletin ve yerel halkın imkânlarını zorlamaktadır. Ayrıca göç etmeye hazır olmayanların, zorunlu göçe maruz kalanların, göçün getirdiği zorluklara hazır olmaması da göç edenlerin durumlarının daha kötüye gitmesine sebebiyet vermiştir.

Göç olgusuna sebep olan bu durumu daha iyi anlamamız için öncelikle yapılması gereken şey Türkiye içerisinde varlığını sürdüren Suriyeli göçmen bireyleri (sığınmacıları) kategorize etmeye çalışmaktır. Bunlar şöyle sıralanabilir: Göçün ilk yıllarında rejim yanlısı ve muhalif göçmenlerden oluşan siyasî temelli göç edenler; planlı şekilde göç edip maddî sermayelerini yanında taşıyan ve ekonomi-sosyal sermayelerini Türkiye'de dönüştürebilen sosyal ve ekonomik temelli göçmenler; akabinde hayatlarını kurtarmak için kaçarak Türkiye’ye geçen ve sosyo-ekonomik sermayeleri düşük olan göçmenler, sonrasında Hristiyan, Müslüman, Alevi, Sünnî, Ezidi vb, dinî ve mezhepsel ayırım neticesinde göç edenler devamında Arap, Türkmen, Kürt, Ezidi vb. etnik temelli göç edenler, DEAŞ teröründen kaçan göçmenler, ayrıca Irak Savaşı'ndan Suriye'ye yerleşen Iraklılar da Suriye’den Türkiye'ye göç etmişlerdir. Son olarak da 40 binden fazla Suriyeli bebeğin Türkiye'de doğduğu tahmin edilmekle birlikte göç neticesiyle gelen ve sayıları giderek artan çok fazla Suriyeli olduğu bilinen bir gerçekliktir. Bu çerçevede, konuyla ilgili çalışmalara baktığımızda daha çok ekonomik sorunlarla birlikte, toplumsal uyuma, kültürel farklılaşmalara ve yerel düzeydeki algılara dönük

8 Türkiye’de sığınan Suriyeliler'in, eğitim, sağlık gibi sosyal haklardan yararlanmaları, suça karışanların takibi için 2013 yılında biyometrik kimlik çalışması başlatıldı. AFAD (Afet ve Acil Durum Yönetimi Başkanlığı) koordinasyonunda yürütülen çalışmada parmak izi, kimlik ve ikamet bilgileri alınan 2 milyon 138 bin 977 Suriyeli'ye biyometrik kimlik verilerek kayıt altına alındı. Resmi kayıt altına alınan Suriyeliler’e "geçici koruma statüsü" de verilmiş olundu.

http://www.hurriyet.com.tr/turkiye-2011den-bu-yana-2-1-milyon-suriyeli-multeciye-8-milyar-dolar-harcadi-40007235 (Erişim tarihi: 06.02.2016)

9 Türkiye Nisan 2011- Aralık 2015 verilerine göre, göçmenler için 8 milyar dolar harcama yapmıştır ve yapmaya da devam etmektedir. Buna karşın resmî verilere göre Birleşmiş Milletler ve Avrupa ülkelerinden gelen yardım miktarı sadece 418 milyon dolar civarındadır. ( T.C. GSMH'sinin \% 0, 21, Milli Gelirine göre en çok insanî yardım yapan ülke) 
sorunların öne çıkarılması rastlantısal değildir. Suriyeden göç ile birlikte, özellikle kamplarda konumlandırılan sığınmacıların insanî şartlarda yaşamasını temin etmek amacıyla Türkiye önemli bir ekonomik külfet altına girmiştir. Ayrıca kamp dışında yaşayan sığınmacıların ekonomiye dolaylı yollardan etkileri de tartışılmaktadır. $\mathrm{Bu}$ anlamda Suriyeliler 'in ekonomik alandaki etkilerine genel olarak bakıldığında risk ve fırsatların iç içe geçtiği bir tablonun ortaya çıktığı görülmektedir. Bu etkilerden en önemlileri; alternatif işgücü nedeniyle ücretlerde yaşanan düşüşler, Suriyeli s1ğınmacıların yoğun olduğu illerdeki kira artışları, işsizlik oranlarındaki yükselişler, enflasyona olumsuz etkileri, kaçak işçi oranlarındaki artış, haksız rekabet algısı ve yerel halkın iş fırsatlarının azalması bağlamında sığınmacıları sorumlu tutması gibi sorunlar ifade edilmektedir.

\section{Barınma Merkezlerindeki Suriyeliler Afad 13.04 2015}

\begin{tabular}{|c|c|c|}
\hline SIRA & İ & SURİYELİ SAYISI \\
\hline 1 & $\begin{array}{c}\text { ŞANLIURFA } \\
\text { (5 Barınma Merkezi) }\end{array}$ & 102.106 \\
\hline 2 & $\begin{array}{c}\text { GAZİANTEP } \\
\text { (5 Barınma Merkezi) }\end{array}$ & 49.346 \\
\hline 3 & $\begin{array}{c}\text { KİLİS } \\
\text { (2 Barınma Merkezi) }\end{array}$ & 36.549 \\
\hline 4 & $\begin{array}{c}\text { KAHRAMANMARAŞ } \\
\text { (1 Barınma Merkezi) }\end{array}$ & 17.295 \\
\hline 5 & $\begin{array}{c}\text { HATAY } \\
\text { (5 Barınma Merkezi) }\end{array}$ & 15.071 \\
\hline 6 & $\begin{array}{c}\text { MARDİN } \\
\text { (3 Barınma Merkezi) }\end{array}$ & 13.792 \\
\hline 7 & $\begin{array}{c}\text { ADANA } \\
\text { (1 Barınma Merkezi) }\end{array}$ & 11.030 \\
\hline 8 & $\begin{array}{c}\text { ADIYAMAN } \\
\text { (1 Barinma Merkezi) }\end{array}$ & 9.8881 \\
\hline 9 & $\begin{array}{c}\text { OSMANIYE } \\
\text { (1 Barmma Merkezi) }\end{array}$ & 9.187 \\
\hline \multirow[t]{2}{*}{10} & $\begin{array}{c}\text { MALATYA } \\
\text { (1 Barınma Merkezi) }\end{array}$ & 7.579 \\
\hline & $\begin{array}{c}\text { TOPLAM } \\
\text { (25 Barınma Merkezi) }\end{array}$ & 257.625 \\
\hline
\end{tabular}

Bu korunma (barınma) merkezlerinden 19'u çadırkent, 6'sı ise konteynerkentten oluşmaktadır.

\section{İlişkisel Sosyoloji Açısından Göç ve Suriyeli Kadın Sığınmacılar}

Sosyolojinin içerisinde yeni bir alan olan “ilişkisel sosyoloji” (Powell ve Depelteau, 
2015, s. 15-16) toplumsal hayatın toplumsal ilişkileri inceleyerek araştırılması ile ilgilidir. Toplumsal olguları tarihin belli bir alanında var olan ve bireylerden ayrı bir gerçekliğe sahip olarak değil; bütüncül bir bakış açısıyla ve bireyci eğilimlerine karşı toplumsal ilişkilere odaklanmaktadır. İlişkisel sosyoloji ne sadece yapıyla ne de sadece faille ilgilenir. İndirgemeci anlayıştan kaçınır. Toplumsal olguları yapıların veya aktörlerin bir sonucu olarak açıklanması gerektiği değil ikisi arasındaki ilişkinin araştırılmasına ve açıklanmasına odaklanır (Emirbayer, 1997, s. 281-317). İlişkisellik, sermayeleri, bireyleri, örgütlenmeleri ve hatta ulusları eylemlerini kişisel bilinç veya doğrudan temas ya da denetimin ötesinde biçimlendiren geniş ilişki ağları açısından bağımsız bilimler olarak kavramsallaştırmak demektir (Bourdieu, 2015c, s. 48). Tarihsel, toplumsal ve siyasî gelişmeler çerçevesinde süreç ekseninde yapıların-kurumların ve bireylerin-aktörlerin etkileşimiyle gerçekleştirdiği ilişki yumakları ilişkisel sosyolojinin merkezî kavramını oluşturur. Dolayısıyla göçün kadın üzerindeki etkisinin ilişkisel incelemesinde sığınmacı durumundaki kadın sadece fail-birey olarak ele alınıp irdelenmediği gibi sadece yapının bir durumu olarak yapıyla-kurumla da irdelenemez. Çünkü bu bize gerçeği ifşa ettiremez. Sığınmacı durumundaki kadının fail olarak yapıyla tarihsel, kültürel bağlamı arasındaki etkileşim sonucundaki ilişkilere bakılarak ele alınıp irdelenmesi gerekmektedir.

İlişkisel sosyoloji bakış açısıyla sığınmacı olgusuna baktığımızda öncelikle bu probleme etki eden ve bu problemi doğuran göç kavramını sorgulamak gerekir. Çünkü göç, ilk başlarda bir yer değiştirme (coğrafi mekân değiştirme) hareketi olarak değerlendirilse de, göçün nedenleri ve sonuçlarıyla birlikte, bireyler ve topluluklar üzerinde geniş çaplı değişim ve dönüşümler yarattığı bir gerçektir. Bu nedenle sosyo-kültürel bir hareketlilik olarak göç, bir sosyo-ekonomik sistemden diğerine, bir kültürel örüntüden diğerine geçmeyi de içermektedir. Yani göç, coğrafi mekân değiştirme sürecinin yanı sıra sosyal, ekonomik, kültürel ve politik boyutlarıyla toplum yapısını değiştiren nüfus hareketleridir (Bayhan, 1997, s. 78-193). Göçle, içinde yaşadıkları coğrafi ve sosyo-kültürel çevreye giren insanlar, yeni çevrelerinde değişmelere neden oldukları gibi, kendileri de değişmektedir (Durugönül, 1997, s. 95-100). Göç olgusunun küresel bir niteliğe büründüğü, hızlandığı ve çeşitlendiği bu nedenle de birçok ülkenin sadece tek tip göçle değil, işgücü göçü, mülteci - sığınmacı veya kalıcı yerleşim gibi sorunlarla da uğraştığı bilinmektedir (Castles, Hass ve Miller, 2013, s. 10-14). Bu sorunlar daha önceleri ele alınırken göçün ana aktörü olarak erkek kabul edilmekte ve kadının erkeği takip ederek göç ettiği ve göç eden erkeğin gittiği ülkede iş bulduktan sonra eşini ve çocuklarını da yanına alarak göç döngüsüne dâhil olduğu kabul edilmekteydi. Bu nedenle kadınlar aile, erkekler de iş yaşamı içerisinde ele alınarak göç olgusu analiz edilmekteydi. Ama bu bakış açısıyla günümüzdeki göç olgusunu Suriye’den zorunlu kitlesel dış göç problemini ele alıp inceleyemeyiz. Çünkü bu göç olgusunda yarısından fazlasını kadın ve çocuklar oluşturmakta ve ayrıca kadınların çoğu erkeklerini takip etmeden sadece kendileri ve çocuklarıyla birlikte yasal ya da yasa dişı yollardan göç ederek mülteci-sığınmacı durumuna düşmüşlerdir. Bu nedenle zorunlu kitlesel göçten en çok kadın ve çocuklar olumsuz etkilenmektedir. Örneğin, Avrupa Polis Örgütü Europol, son iki yıl içerisinde 10 binin üzerinde göçmen çocuğun 
Avrupa Birliği (AB) ülkelerine geldikten sonra kaybolduğunu açıklamıştır. Göçmen kadın ve çocukların insan ticaretinin önemli mağdurları olduğu bu sorundan kaçmak için de göçmen aileler kız çocuklarını küçük yaşta evliliğe zorladıkları da göz ardı edilemez bir gerçekliktir. Bu nedenle göç olgusunda kadının yeri ve konumu önem arz etmektedir. Dolayısıyla göç; kadın göçünden, kadın göçü de toplumsal cinsiyetten ayrı ve bağımsız olarak düşünülemez.

\section{Bourdieu'nün Kavramları Bağlamında Suriyeli Kadın Sığınmacılar ve Yoksulluk}

Göçün insanlar üzerindeki etkileri, göç nedenleri (gönüllü-zorunlu), göç modelleri (içe ve dişa göç), ne kadar süreyle göç edildiği (geçici, döngüsel ya da kalıcı) önemli kriterlerdir. Göç ettikleri yerin koşulları, orda yaşayanların sosyo-kültürel durumları, göçmenlerin eğitimi, yaşı, cinsiyeti, normlar vs. kültürel değişkenler gibi pek çok etkene bağlı olarak değişmektedir. Göç eden insanlar, gittikleri yerlere sahip oldukları kültürel birikimlerini, sermayelerini de beraberinde götürürler. Dolayısıyla kültürel geçmiş göç sonrası yaşamı biçimlendirmede önemli bir faktör olarak etki eder. Örneğin birey (fail) yeni göç ettiği yere geldiği zaman aslında kendisinin özgür bireysel verdiği bir kararmış gibi görünse de onu bu eyleme iten yapısal-kurumsal nedenler vardır. Ayrıca da birey bu göç etme esnasında aslında kendisiyle beraber getirdiği bilinçli ve bilinçsizce farkında olduğu ya da olmadığı birtakım eğilimleri, yatkınlıkları, algıları, duyguları, eylemleri bulunmaktadır. Bir kişinin algıları, duyguları ve eylemlerini bilgilendiren ve sosyal olarak içselleştirilmiş bir dizi eğilimlere Bourdieu "Habitus" (Bourdieu ve Chartier, 2014, s. 61-62) adını vermektedir. Habitus, bireylerin sosyalleştikleri süre içerisinde (çoğunlukla ilköğretim, yetişkinlikte ortaöğretim) az çok bilinçsiz bir şekilde içselleştirmiş ve benimsemiş olduğu idrak (dünyasının nasıl alg1layacağına dair) ve eylem (nasıl davranacağına dair) şablonlardan meydana gelir (Jourdain ve Naulin, 2016, s. 42). Aynı zamanda bireylerin bedenlerine zihinsel ve bedensel algı, beğeni ve eylem şemaları biçimde konulmuş bir tarihsel bağıntılar bütünü biçimini alır (Bourdieu ve Wacquant, 2014, s. 25). Yani habitus vücuda, biyolojik bireye yazılmış toplumdur. Yapıdan kaynaklanan doğaçlamadır. Habitus bireyin bilinçdışının sosyal yapılarla etkileşimi aracılığıyla zaman içinde yeniden üretilir ve evrimleşir (Bourdieu ve Passeron, 2015, s. 38-43) ve bireyleri kendi sosyal sınıf gruplarının diğer üyelerine benzer şekillerde yaşamaya yönelten sosyal olarak edinilmiş bir dizi vücut bulmuş eğilim olarak tanımlanır (Bourdieu, 2015a, s. 254). Çoğunlukla belirli bir grup habitusunda doğup yetiştikleri için bireyler habitusun onların düşünme, algılama ve hareket etme ve çevrelerindeki dünyayla iletişim kurmalarını nasıl hem mümkün kıldığını hem de sınırlandırdığını genellikle fark etmez. Bireyin ait olduğu geniş grubun eğilimlerinin vücut bulması olarak habitus, insanlara ne tür bir kişi oldukları ve kendileri gibi insanları ne düşünmesi ve hissetmesi ve ne tarzda hareket etmesi gerektiği hakkında net bir anlayış sunar (Thorpe vd. 2015, s. 76-78). Dolayısıyla göç olgusunda Suriyeli kadın sığınmacılar içinde doğup büyüdüğü toplumda kendi habituslarıyla beraber göç etmektedirler. Suriyeli sığınmacılar göç ettikleri ülkeye yerleşme sürecinde otogarlar, parklar, konteyner kentler, çadır kentler, misafirhaneler, şehir merkezlerinde kendi imkânlarıyla kiraladıkları evler vs. gibi kendi sos- 
yo-kültürel sermayesi ölçüsünde ve kendi habitusları ekseninde alanlara giriş yaparlar. Alan kavramı ile Bourdieu, toplumsal uzamın aşırı yapısalcı yorumunu yani içerisinde çeşitli pozisyonlar işgal eden bireylerin, onları sarmalayan ve kuşatan yapısal ilişkilerin sadece taşıyıcıları olmadığını ifade eder. Bourdieu, aksine alan kavramıyla bireylerin bir mücadele, oyun alanı, strateji geliştiren ve uygulayan mekânlar olarak bahseder. Bu noktada alan kavramı Bourdieu’nün ifade ettiği gibi bir alana katılan bütün bireyler, alanın varlığına bağlı olan şeyler gibi kendi ortak çıarına uygun şekilde hareket eder. Ayrıca alanlara yeni giren Suriyeli sığınmacıların beraberinde getirdikleri sermaye sadece ekonomik (servet, gelir, taşınabilir mülk) değildir. Bireyler için farklı toplumsal kaynak oluşturan farklı türdeki sermayeler de vardır. Örneğin "kültürel sermaye"10 de bunlardan biridir. Bourdieu kültürel sermaye kavramını, sözel beceri, dil, tüketim alışkanlıkları, satın alma gücü, genel kültürel farkındalık, dinî aidiyet, eğitimsel birikim, yeme alışkanlıkları, estetik tercihler, sanat eserleri yargısı ve beğenisi, müzik vs. olarak kültürel sermayeyi somutlaştırmıştır. Bourdieu, bireyin habitusunun bir kişinin sahip olduğu "mevcut olarak kullanılabilir kaynaklar ve güçler kümes”" olarak yeniden tanımladığ 1 sermayenin farklı türleri (ekonomik, kültürel, simgesel ve sosyal) ve miktarlarından oluştuğunu ileri sürer. Habitus ve kültürel sermaye toplumsal deneyimlerimizin bir sonucu olmasının yanında zihnimizde taşıdığımız sınıf, dil, toplumsal cinsiyet, eğilim ve yatkınlıklarımız; dünyayı algılayış ve yorumlayış tarzımızı teşkil eder. Dolayısıyla Suriyeli kadın sığınmacılar kendi habituslarını ve kültürel sermayelerini de göçle beraberinde getirirler ve geçmiş tecrübelerle gelecek eylemler arasında zihinsel bir algılayış tarzı olarak bugünlerini ve yaşadıkları sığınmacı ve göçmen sorununu yoksulluk ekseninde yaşayarak hem uyum sağlamaya hem de çözümlemeye çalışarak mücadele etmektedirler. Bu nedenle sığınmacılık ve göçle ilgili problemlere uygulanan ve uygulanmak istenen çözüm yolları esnasında Suriyeli kadın sığınmacıların habitusları ve kültürel sermayeleri de dikkate alınarak hareket edilmesi gerekir. Örneğin Suriyeli kadın sığınmacıların en büyük yoksulluğu, eğitimden yoksun olmalarıdır. Toplumsal hayatta kadının ikinci planda olduğu ve yeterli eğitime sahip olmadığı sadece ev işlerinde çocuğuna bakmakla yükümlü olduğu; cinsiyete dayalı bir iş bölümünün olduğu "eril tahakküm” (Bourdieu, 2015b, s. 17) ün hâkim olduğu bir habitustan ve kültürel sermayeden gelen Suriyeli kadın sığınmacılar, göçle beraber getirdikleri ve sahip oldukları habitusa ve kültürel sermayeye göre çözüm yolları geliştirerek alanlarda hareket ederler. Suriyeli kadın mültecilerin büyük çoğunluğu Türkiye koşullarında çalışma hayatına giremediklerinden yaşadıkları sığınmacı ve yoksulluk sorunlarıyla başa çıkmakta zorlanmaktadır ve

10 Bourdieu Marks’ın üst yapı-alt yapı ikiliği ayrımını eleştirerek genişletir. Sermayenin sadece ekonomik temelli olmadığını, kültürel, simgesel, sosyal ve ekonomik olduğunu ifade eder. Yani Marks toplumsal hayatı çözümlerken yalnızca ekonomik ilişkileri kriter olarak almaktayken, Weber ekonomik, sosyal ve siyasal düzendeki ilişkileri kriter olarak alır. Bourdieu ise ekonomik ilişkilerin yanında kültürel, sosyal ve simgesel ilişkileri de ana kriter olarak almaktadır. Marks toplumları birbirine ayrışmış ve çatışma halindeyken ifade eder; Weber ise toplum tabakalar halinde bütünleşmiş olduğu için çatışma çıksa bile belirleyici olmadığını iddia eder. Bourdieu da ise sınıfların varlığı farklılıklar uzayı olarak kabul eder ve çatışma bu sınıfların sınırlarını belirlemede oluştuğunu ifade eder. Marks’a göre sınıflar arası geçiş ancak bir devrimle gerçekleşebilir, Weber de ise tabakalar arası sosyal hareketlilik vardır. Bourdieu ise bu hareketliliğin geçirgenliğin kolay olmadığını belirtir ve bireyler bir üst sınıfa girdiklerinde hangi kökenden geldiklerini belli ederler. Bir kaç kuşak sonra mümkün olabilir. 
tamamıyla Türkiyede ya devlet nezdinde ya da gönüllü yardım kuruluşları nezdinde onlara barınma imkânı sağlayan kamplarda, misafirhanelerde geçimlerini kendi kültürel sermaye ve habituslarıyla ilişkilendirerek yaşamaktadırlar. Örneğin Türkiye'deki sığınmacı kamplarında, misafirhanelerinde, konaklama tesislerinde bulunan Suriyeli kadın sığınmacılar kendi çocuklarına bakarak ve yaşamlarının çoğunu kendilerine tahsis edilen barınma evlerinde geçirerek hayatlarına devam ettirmektedirler. Ya da onlara terzilik, kuaförlük, saç bakımı gibi aslında kendi ihtiyaçlarını karşılayabilecek meslekî alanlar oluşturulmaktadır. Bu alanlara onlar özgür olarak kendi fail olarak seçtiği ve tercih ettiği bir durummuş gibi algılasalar da aslında ilişkisel sosyolojik bağlamda söz konusu durum yapının da bir edimiyle kendi ülkelerinden göçle beraber getirdikleri habitus (içselleştirilmiş ve bedenselleştirilmiş toplumsal yapılar) ve kültürel sermayelerinin bir sonucudur. Aslında hem sığınmacı kadınların kendilerine hem de yapının onlara atfettiği bir tercihtir. Tercih edilen bu meslekler Bourdieu'nün eril tahakküm olarak adlandırdığı ve tahakkümün ürünü olan düşünme biçimlerinin dışa vurulmuş halidir. Cinsiyete dayalı bir işbölümünün ve erkek merkezli bakış açısı temel alınarak oluşan eril tahakküm, gücünü ve etkisini egemenlik altına aldığı kadınların bu egemenliği meşru ve doğal kabul etmelerinden kaynaklanmaktadır. Diğer bir değişle kadınlar, boyun eğme durumunu kendi rızalarıyla, bilinçli olarak değil, ama aksine zorlama da olmaksızın kendiliğinden razı olurlar. Eril tahakküm tüm toplumsal düzenin işleyişinde belirgindir, kadınlar da bu düzenin bir ürünü ve devam ettiricisi olarak eril tahakkümü doğal ve normal olarak kabul etme eğilimindedirler. Bourdieu bu durumu "sembolik şiddet" (Bourdieu, 2015b, s. 73-77) kavramını kullanarak açıklar. Yani eril tahakkümün ortaya koyduğu hâkimiyet, ürettiği simgesel şiddet aracılığıyla kadınları hükmedilmeye razı ederek devam eder. Simgesel şiddetin kurbanı olan kadınlar, dünyayı eril tasvir sistemiyle algılamaya mecbur bırakılmaktadır. Böylece Suriyeli kadın sığınmacılara tahakküm ilişkileri mantığı tarafından dayatıldığı veya telkin edildiği bir gerçeklik söz konusudur. Hükmedilenler, tahakküm ilişkilerine hükmedenlerin bakış açısıyla oluşturulmuş kategorilerle bakarlar, bu da kategorilerin doğalmış gibi görünmelerine yol açar. Bu onları sistematik bir şekilde kendi kendini değersizleştirmeye, hatta aşağılamaya kadar götürebilir (Bourdieu, 2015b, s. 50). Tahakkümün nedeni ne olursa olsun ister cinsiyet ister kültür, ister dil; bu habitustan (vücuda, biyolojik bireye yazılmış toplumdan) kaynaklanmaktadır. Ayrıca her habitus kendini devam ettirmenin yanında bir grubun üyelerinin paylaştı̆̆ ortak deneyimleri sağlar ve grubu tanımlayıp ona kimliğini kazandıran toplumsal bir topoğrafya üzerinde temellenir. Bu paylaşılan durum Bourdieu'nun "alan" adını verdiği şeydir. Alan Bourdieu'nün sosyolojisindeki kilit mekânsal metaforlarından birisidir. İnsanların habituslarını ifade ettiği ve sürekli olarak yeniden ürettiği çeşitli sosyal arenalara veya alanlara (örneğin kurumlar veya gruplara) girmeden önce ilişkiler dahilinde (aile ve okul gibi) gelişir. İnsanların girdikleri alanlarda başarılı olup olmadığı, sahip oldukları habitus türüne ve bunun taşıdığı sermayeye bağlıdır. Alan, habitusun işlev gördüğü toplumsal ortamın yapısını belirler. Alanlar, malların, hizmetlerin, bilginin ya da statünün üretildiği, dolaşıma girdiği ve temellük edildiği arenaları ve aktörlerin bu farklı sermaye türlerini biriktirip tekellerine alma mücadelesinde işgal ettikleri rekabete dayalı konumları ifade eder (Swartz, 2013, s. 167). Bourdieu sürekli olarak ekonomik 
alan, sanatsal alan, siyasî alan, bürokratik alan, akademik alan, yasal alan, edebî alan vb. bahseder (Bourdieu, 2015c, s. 238). Bourdieu’nün alan kuramı konumlar arasındaki konfigürasyonun bir kuramıdır. Bu konumlar, gerek var oluşları gerekse kendilerini işgal edenlere, toplumsal faillere veya toplumsal kurumlara dayattıkları belirlenimler bakımından, farklı sermaye biçimlerinin dağılım düzenindeki mevcut durumlarına göre ayrıca diğer konumlara nesnel bağıntılarına (tahakküm, itaat, benzeşme vb.) göre nesnel olarak tanımlanır (Tatlıcan \&Çeğin, 2010, s. 318). Yani kısaca Bourdieu nüfuslar, gruplar, örgütler ya da kurumlar yerine alanlardan söz etmektedir. Suriyeli kadın sığınmacılar, habitusları ve kültürel sermayeleriyle toplumsal alanlarda mücadele ederek hareket etmektedir. Alan mücadelesi ekonomik, kültürel, bilimsel veya dini sermaye gibi belirli sermaye biçimleri etrafında döner. Meşruiyet mücadelesi arenaları olan alanlar, Bourdieu kavramsallaştırmasıyla "simgesel şiddet" kullanma hakkını tekeline alma mücadelesidir (Swartz, 2013, s. 174). Bu durumda Suriyeli kadın sığınmacılar kendileriyle beraber göç esnasında getirdikleri habitusu ve kültürel sermayeleri aslında yeniden üretilmekte ve devam etmektedir. Bourdieu, bu noktada habitusun kendisini üreten ve yeniden üreten yapılardan ayrı düşünülemeyeceğini belirterek, asimetrik bir ayrım olan cinsiyet ayrımının ve bundan türeyen eril tahakkümün hem toplumsal yapılarda hem de algı şemaları ve habitusta oluştuğunu ve yeniden üretildiğini vurgulamaktadır (Bourdieu, 2015b, s. 48-51). Toplumsal eşitsizliğin bir göstergesi olan ve görünmez şiddet olarak da adlandırılabilecek olan sembolik şiddet terimiyle Bourdieu, insanların silah gücünden değil aksine yanlış anlamanın gücünden zarar görmeleri veya engellenmelerini kasteder (Tatlıcan ve Çeğin, 2010, s. 119). Yanlış bir kanaati ve meşru görülen sabit bir fikri ya da toplumda yerleşmiş hâkim kanaatler bütününü, yanlış tanılamaları Bourdieu "doxa"11 olarak adlandırır. Toplumun her alanında (ekonomik, sanat, siyaset, din vs.) o alanların işlerliğini sağlayan ve o alana katılanların alanın kurallarına uygun eyleme yöneten "doxa"dır. Doxa alanın yapısallığını toplumsal faillerin gözünde normal ve doğal kılarak meşrulaştırır. Böylelikle doxa etkisi altındaki katılımcılar, alandaki örtük tahakküm ilişkilerini ve eşitsizlikleri yeniden üretir. Örneğin "Suriyeli sığınmacılar tembel ve açgözlü yoksullar olduğu", "Çalışmak istemeyip dilencilik yaptığı", "Suriyeli sığınmacılar geldi Türkler işsiz kaldı", "Yabancılar ve göçmenler bizim işlerimizi çalıyorlar", "Türkiyedde işçi ücretleri düştü" gibi birbirine zit söylemler yanlış tanılama biçimidir, yani doxadır. Çünkü söz konusu işler ve ücretler zaten Suriyeli mülteciler gelmeden önce vardı ama Türkler bu fiyattan çalışmak istemiyorlardı. Yani sığınmacılar daha çok yerli halkın yapmadığı işleri yapmak zorunda kalmaktadır. Dolayısıyla söz konusu doxaların varlığı problemi açmazlara sürüklemekte ve olumsuz sonuçlar doğurmaktadır. Doxalar yanlış tanılama biçimidir. Bu bağlamda sosyoloji tam da bu noktada işlevsellik kazanmaktadır ve sosyoloğa düşen görev ilişkisel bakış açısıyla sorunsalı tüm gerçeğiyle ifşa etmek olmalıdır.

11 Bourdieu doxayı bir araştırmanın her yanına dağılmış, söylenmeden, sessizce kabul edilen görüşler olarak tanımlamıştır. 


\section{Sonuç}

\section{Suriyeli Kadın Sığınmacılar ve Yoksulluk: Malatya Örneği}

Türkiye'nin komşusu olan Suriye'den ve Irak'tan düzensiz kitlesel dış göç almış olması ve almaya devam ediyor olması, Birleşmiş Milletler Mülteciler Yüksek Komiserliğinin (UNHRC -BMMYK) 2015 yılının son verilerine göre ifade ettiği gibi Türkiye’yi dünyada en büyük sığınmacı ülkesi haline getirmiştir. Üçüncü ülkelere geçmeyi arzu eden ancak bunu başaramayan ve Türkiye'de ikamet etmek zorunda kalan göçmenlerin- s1ğınmacıların sayısı önemli derecede artmaktadır. Bu durum Türkiye’yi "göç veren" ve "transit" bir ülke olmasının yanında ayrıca "hedef" ülke haline de getirmiştir. 2013 yılında 6458 sayılı Yabancılar ve Uluslararası Koruma Kanunu’nu çıkaran Türkiye, İçişleri Bakanlığı bünyesinde göç yönetiminden sorumlu müstakil bir idari birim olarak Göç İdaresi Genel Müdürlüğünü kurmuştur. Dolayısıyla beklenmedik bir göç akını etkisinde kalan Türkiye, hem idarî yapıda hem de toplumsal yapıda ciddi değişiklikler yapmıştır ve yapmaya devam etmektedir. Ayrıca Suriye'den göç edenlerin yüzde 80'inden fazlasını kadın ve çocuklar oluşturduğundan Türkiye sınıra yakın on ${ }^{12}$ ilde yirmi beş barınma merkezleri yapmıştır. Gelen kişilere barınma, sağlık, güvenlik gibi acil temel ihtiyaçlarına öncelik verilerek sonrasında psikolojik ve sosyal boyutun öne çıtığı düzenlemeler çerçevesinde ihtiyaçların giderilmesi sağlanmaya çalışılmıştır. Bu barınma merkezlerinden biri olan ve örnek kamp olan Malatya Beydağ ${ }_{1}$ Konaklama Tesisleri (MABEK) $)^{13} 12$ Haziran 2013'te Suriyeli sığınmacıları kabul etmeye başlamıştır. 2125 Konteyner sayısı ve her konteynerin kullanım alanı 21metrekaredir. 6 Mahalle (Ankara, Şam, İstanbul, Halep, Konya ve Hama), 7 Cadde ve 118 Sokak bulunan Malatya Beydağı Konaklama Tesisleri’nde Suriyeden gelen sığınmacı misafirlerimiz için "geçici barınma" hizmetleri sunulmaktadır. Bu hizmetlerin bazıları: yardım, barınma, yiyecek, sağlık, güvenlik, sosyal aktivite, eğitim, ibadet, tercümanlık, haberleşme, temizlik vb'dir. Ayrıca Malatya Beydağı Konaklama Tesisleri’nde Suriyeli kadınlar kuaför, terzilik, öğretmenlik gibi kendi ihtiyaçlarını kendilerinin karşıladığı meslekleri de yapmakta ve çocuklarını okula verebileceği, anaokulu, MABEK lisesi gibi okulların olduğu, çocuk parklarının olduğu, basketbol, voleybol sahalarının olduğu kısaca maddî manevî imkânlarının sağlandığı bir yerdir. Malatya Beydağı Konaklama Tesisleri ayrıca kültürel şoka ilişkin tampon bir mekanizma görevi de görmektedir. Haftanın iki günü yani salı ve perşembe günleri kendilerine izin verilerek kent merkezini gezmektedirler. Eğitim ve sağlık başta olmak üzere tüm ihtiyaçları kampta karşılanan sığınmacılar ülkelerindeki savaşın bitmesi halinde ülkelerine dönebileceklerini ifade etmektedirler. Türkmen ağılıklı sığınmacıların yaşadığı kampta öğrenciler hem

12 Adana, Adıyaman, Hatay, Gaziantep, Kahramanmaraş, Kilis, Malatya, Mardin, Osmaniye, Şanlıurfa.

13 Başbakanlık Afet ve Acil Durum Yönetimi (AFAD) başkanlığının 14.11.2012 tarih ve 497 sayılı mesaj emirleri doğrultusunda Malatya İlinin Merkez Fatih Mahallesi sınırları içerisinde 10 bin kişi kapasiteli 2 bin adet konteynerden oluşan konuklama tesisi kurularak, 12 Haziran 2013 tarihi itibariyle Suriyeli Sığınmacıların kabulüne başlanmıştır. Toplam alanı: 433.000 metrekare; Toplam Konteyner Kent alanı: 276.000 metrekare. Ağaçlandırma Alanı: 160 dekar. (25.04. 2015 Tarihli Brifing) 
Türkçe hem de Arapça öğrenmektedir. Satranç, tenis, masa tenisi, hentbol, çim hokeyi gibi sportif faaliyetlerin ve mobilyacılık, dikiş-nakış, triko, halıcılık, folklor, resim, ebru, hadis, fıkıh, Kur'an gibi dinî kursların da olduğu Malatya Beydağı Konaklama Tesisleri'nde (MABEK) konteyner kent içerisinde sağlık ocağı da bulunmaktadır. Ayrıca MABEK, sığınmacılara özellikle de sığınmacı çocuklara, belirsizliği, güvensizliği, muğlaklığı, yoksulluğu ve dışlanmayı manipüle eden korunaklı güvenli yerlerdir.

Malatya Beydağ 1 Konaklama Tesislerinin (MABEK) dışında kent merkezinde yaşayan Suriyeli sığınmacılar da bulunmaktadır. Malatyada yaşayan sığınmacıların büyük çoğunluğu Türkmen ağırlıklı Suriyeli sığınmacılardır. Sığınmacı ailelerde hemen hemen Türkçe bilen bir birey olsa da Suriyeli sığınmacıların gündelik yaşamlarında en çok yoksullukla maruz kaldığg etken maddî yetersizlikten ziyade dil engeli ve yetersizliğidir. Bu ayrıca gündelik yaşam içerisinde Türk komşularıyla yani Malatya yerel halkıyla da özellikle de komşularıyla aralarındaki iletişim problemlerini oluşturmaktadır. Birçoğu komşularıyla aralarındaki tek engelin dil problemi olduğunu ifade etmiştir. Kampların dışında yaşayan belli bir beceri ve yetenekleri olan özellikle Suriye'de ayakkabıcılık, temizlik, tarım ve inşaat sektöründe çalışan ustaların Malatya toplumu içerisinde daha kolay uyum sağladığı gözlenmiştir. Ayrıca kendi bilgi ve birikimleriyle belli iş kollarının aradığı ara eleman olarak daha kolay bir şekilde istihdam edildiği görülmüştür. Aslında bunun en önemli sebebi emek piyasasında göçmen işçiye duyulan talep olmuştur. Örneğin kayısı bahçelerinde işçi olarak çalışan sığınmacilar gözlenmiştir. Malatya Beydağı Konaklama Tesislerinde yaşayan Suriyeli kadın sığınmacıların kendi yerel kıyafetlerini daha çok tercih ettiği görülmüştür. Örneğin MABEK’te bonesiz ve tek renk olarak taktıkları Suriye tarzı başörtülerini takmakta olduğu ve özellikle orta yaş üzeri Suriyeli erkeklerin yerel Arap kıyafeti olan “jellabiye” giydiği gözlemlenmesine rağmen kamp dışında Malatya kentinde yaşayan sığınmacılar ise daha çok Malatya yerel halk gibi giyindikleri gözlemlenmiştir. Ama yine de kendi yerel kıyafetleriyle giyinen sığınmacılar Malatya kentin de gözlemlense de bu durum MABEK' te daha fazladır. Bourdieu kavramıla yeni girilen alanda kendi stratejisini kendi habitus ve sermayesi ölçüsünde sığınmacılar alanda mücadele ettiği söyleyebiliriz. Yani Bourdieu söylemle, sığınmacılar alanda göç ettiği Malatya ilinde yerel halkın mekânların da kendi oyunlarıyla, stratejileriyle hareket etmektedir.

Malatya ilinde yerel halktan bazıları (özelliklede kitle iletişim, televizyon ve internetin etkisiyle gördükleri ve algıladıkları) iç savaştan kaçan Suriyeliler'i "kendi ülkelerindeki savaştan kaçtıkları için yanlış yaptıklarını” ifade edip sığınmacıları suçlayıcı söylemlerle itham edip ülkelerine dönüp savaşmaları gerektiğini belirtmişlerdir. Tersine bazıları da misafir, ümmet, muhacir gibi kavramların etkisiyle "kaçmayıp ne yapsalardı?" gibi söylemlerle sı̆̆ınmacıların misafir olduklarını ve bizim onlara yardım etmemiz gerektiğini ifade etmişlerdir. Suriyeli sığınmacıların çoğu da Türkiye’ye karşı borçlu hissetmelerine rağmen sığınmacı olarak kalmak istemediklerini ifade etmişlerdir. Sığınmacılar ülkelerindeki iç savaşın bittiğini gözleriyle gördükten sonra kendi ülkelerine geri dönmek istediğini belirtmişlerdir. Suriye’den kısıtlı bir birikimle gelen Suriyeli sığınmacılar, birikimlerini tükettikleri zaman kendi habitus ve sermayeleri 
ekseninde özellikle Türkler’in yapmak istemediği işleri yapmaktadırlar. Dil engeli, maddi yetersizlik, geçim mücadelesi, farklı bir ülkede hayatta kalma çabası gibi etkilerle sığınmacılar yoksunluk eksenli yoksulluk yaşamaktadırlar.

Türkiye toplumuna entegre olamayan ve yerleşme konusunda başarı gösteremeyen ve kamplarda da yaşamak istemeyen sığınmacılar, özelliklede Avrupa'da eğer bir tanıdı̆̆ı ve akrabası var ise o ülkeye gitmeye çalışmakta ya da Türkiye içerisinde Suriye sınırına yakın illerde bir tanıdığı ve akrabası yok ise İstanbul gibi büyükşehirlere gitmek istemektedirler. İstanbul gibi büyük şehirlerin tercih edilmesinde sığınmacıların bilinçli bir stratejiyle hareket ettiği söylenebilir. Yoksulluğu bir moment olarak değil de bir akış olarak ele alıp "nöbetleşe yoksulluk" kavramı ekseninde kentleşme ve göç dinamiğiyle iç içe geçen temel bir strateji olduğunu ifade eden Işık’a göre yoksulluk nöbetleşerek devam etmektedir (Işık\& Pınarcıoğlu, 2015, s. 38-50). Suriyeli sı̆̆ınmacılar zorunlu kitlesel diş göç ile geldikleri şehirlerdeki yoksul kesimlerin yaşadığı varoş, gecekondu bölgelerinde, kendilerinden çok daha önce gelen göçmenlerin (özellikle de büyük şehirlere doğru iç göçle başlayan gecekondu) evlerini değerinden yüksek fiyatlarla kiraladıkları görülmektedir. Dolayısıyla önceki göçmenlerin yoksulluk nöbetlerinin yeniden üretilerek daha sonra gelenlere devredildiği gözlenmektedir.

Avrupa ülkelerine gitmek isteyen sığınmacılar ise, deniz yoluyla Yunan adalarına veya İtalya kıyılarına ulaşmak istediği, kara yolunu tercih edenlerin ise ilk hedefi Meriç Nehri üzerinden Yunanistan’a ulaşmaya çalıştıkları da sığınmacıların ayrı bir trajedisini göstermektedir. Örneğin Türkiye'de, 2015 yazında Ege Denizi’ni geçerek kendilerine yeni bir yaşam hayali kuran üç yaşındaki Aylan Kurdi’nin kıyıya vurmuş cesedinin fotoğrafı bu trajedinin en geniş bir ölçekte dünya gündeminde yankılanmasına sebep oldu. Aylan’ın ailesinin Kanada'da yaşayan Halası Tina Kurdi’nin yanına gitmek istediği ancak trajediyle sonuçlanan bu durumun nedeni olarak Avrupa'nın kapalı sınır politikası ve göçmenleri istememesi eleştirilerin odağında yer almasına sebep oldu. Ayrıca diğer bir örnek 2015 yazı boyunca Macaristan, mültecilerin/sı̆̆ınmacıların Yunanistan'dan çıktıktan sonra vardıkları ilk AB ülkesi olması nedeniyle hem medyanın hem de $A B$ üye devletlerinin odağında yer aldı. Budapeşte'nin iki ana tren garından birisi ve Batı Avrupa'ya giden trenlerin hareket noktası olan Keleti Garı'nın önüne yığılan ve polis tarafindan trenlere binmeleri engellenen binlerce mültecinin trajedisi yaşandı. Yine Budapeşte’nin merkezine kurulan demir bariyerlere hapsedilen mültecilerin/sı̆̆ınmacıların kendilerine yapılan bu düşmanca tutumu kabul etmeyerek Budapeşte'den Avusturya’ya doğru yürüyüşe başlamasına sebep oldu. Bununla sinırlı kalmayan Macaristan hükümeti, Sırbistan sınırında inşasına daha önceden başladığı tel örgülerinin yapımını hızlandırdı ve tel örgülere dokunmayı bile suç ilan eden yeni bir yasa çıkardı. Aslında bu olaylar hem AB göçmen politikasının hem de Batı́nın göçmenleri ötekileştirip kendinden olmayanı düşman olarak adlandırmasının somut bir kanıtıdır. Macaristan’ın duvarın diğer taraftakilerini dışardakiler, ötekiler, kendilerinden olmayan olarak adlandırması aslında bu durumun Avrupa’nın idrak dünyasının somut bir göstergesidir. Yani Avrupa(li) kimliğinin ve yaşam biçiminin diğer kimliklerden ayırt edilebilir ve üstün olduğu ve bu kimliğin şartlar ne olursa olsun ko- 
runması gerektiğinin idrak edilişini yansıtır. Ayrıca göç neticesinde göçmenler gittikleri yerlere kültür ve kimliğini (kültürel sermayelerini) götürdüklerinden göçülen yerdeki topluma ve yaşama hem uyum sağlamakta zorlanmakta hem de ötekileștirmenin kıskacına düşmektedir. Örneğin kaçak göçmenlerin çoğu Avrupa’da kriminal suçlu, düzeni bozan, fakir, işsiz, sosyal ve ekonomik olarak geride olan, terörist, güvenliği ve kimliği tehdit eden, yükselen işsizlik oranlarının sorumlusu, sosyo-ekonomik tehdit vs. olarak algılanmıştır ve etiketlendirilmiştir. Ayrıca bu durum göçmenlerin ve yabancıların algısını da etkileyerek suçluluk algısının oluşmasına sebebiyet vermiştir. Suçluluk algısının oluşmasında temel etken rutin kimlik kontrolleri, baskınlar ve polis memurlarının uygulamaları olmuştur. Göçmen kavramının suçlu kavramıyla ilişkilendirildiği Avrupa'da göçmenlerin önüne konulan hukukî ve siyasî engellerden dolayı göçmenler hem sosyo-kültürel olarak hem de iş ve sosyo-politik yaşama dahil olamamaktadırlar. Avrupa’da göçmenlere ilişkin böylesi bir algı oluşmasında siyasetçilerin ve medyanın etkisi de yadsınamaz. Özellikle medyada göç olgusu ve göçmenler ile ilgili haberler daha çok suçluluk sorunları, ekonomik kriz, siyasî çatışma, işsizlik ve şiddetle ilişkilendirilerek anılmaktadır. Bu durum Batı toplumlarında göç kavramının tanımı ve algısını da değiştirip dönüştürmüştür. Göç uzun yıllar boyunca Batı için tatmin ve mutluluk kaynağ nağı olarak görülüp algılanmaktadır.

Göçmenlik kavramıyla ilişkili olarak en çok kullanılan kavram aslında yoksulluk ve güvensizliktir. Yoksulluk bağlamında göçmenlere baktığımızda çoğunun mutlak anlamda yoksul olduğu söylenebilir. Örneğin Suriyeli sığınmacıların yarısından fazlası yoksul, yüzde 30'u açlık sınırının altında yaşadığı ve kamplarda kalanların da göreli olarak kendilerini yoksul olarak görebildiğini ifade edebiliriz. Ancak yoksulluk sadece ekonomik anlamda görülmemelidir. Eğitim imkânlarında yoksun olmak, kendi vatan topraklarından yoksun olmak, göç ettikleri herhangi bir ülkede vatandaşlık bağı ile bağlı yaşayamamak ve insanî olarak temel haklardan yoksun olmak en büyük yoksulluk kaynağıdır. Özellikle yarısından fazlası kadın ve çocuklardan oluşan Suriyeli sığınmacılar, ülkelerinde savaş ve şiddet; göç yolunda soygunculuk, insan tacirliği ve göç ettikleri yabancı topraklarda ise belirsiz bir geleceğin kıskacında yaşadıklarından Avrupa'ya ve daha ötesine geçen on binlerce Suriyeli sığınmacıları birçok risk beklemektedir. Azarlanmak, kandırılmak, ekonomik açıdan sömürülmek, fiziksel şiddete ve cinsel istismara uğramak, organ mafyasının ve kadın tacirlerinin eline düşmek gibi insan ticaretinin en önemli mağdurlarını aslında kadınlar oluşturmaktadır ve kadınları birçok risk ve tehlikeler beklemektedir. Bu risk ve tehlikeler karşısında kadın göçmenlerden bazıları erkek gibi giyinmeye başlayıp göç edenler bile var. Ayrıca göçmenler hangi ülkede yaşarsa yaşasınlar, yaşadıkları ülkenin vatandaşları tarafından kabul görmek ve kendini rahat ifade edebilmek için o ülkenin dilini bilmesi gerekmekte fakat Suriyeli kadın göçmenlerin yarısına yakını okuma yazma bilmemesi bu durumu zorlaştırmaktadır. Bu durumda ayrıca kadınlar, nitelikli iş bulma konusunda da zorluk çekmektedirler ve yoksunluk/yoksulluk kıskacına düşmektedirler. Ayrıca devletler kitlesel diş göç ilişkisine "göçmen", "sığınmacı", "mülteci" ayrımı çerçevesinde hareket etmektedir. Çünkü her ülke göçmen ve sığınmacılara karşı kendi ka- 
nunlarını ve politikalarını geliştirirken, mültecilere ise ulusal ve uluslararası kanunlar tarafından belirlenmiş mültecileri koruma ve sığınma kurallarına uygun olarak davranılmaktadır. Dolayısıyla hem kendi habitusları, kültürel sermayeleri açısından hem de göç süresinde vardıkları hangi ülke olursa olsun Suriyeli kadın sığınmacıların en önemli sorunu barınma ve temel vatandaşlık haklardan mahrum kalma yoksunluğu olarak yoksulluktur.

Sonuç olarak Türkiyedeki ve dünyadaki Suriyeli sığınmacılara yönelik çalışmaların büyük bir kısmı mevcut verileri güncelleyerek yineleyen, daha çok nicelik tespitinde bulunan, nitelik - nicelik tespitleri, hukukî ve sosyal konumları, uluslararası ilişkiler içerisinde siyasal ve ekonomik zeminlerde tartışılmaktadır. Ayrıca problemin süreç içerinde değişerek dönüşmesi ve hem ulusal hem de uluslararası küresel bir boyutta olması sığınmacılar üzerindeki çalışmaları zorlaştırarak sınırlamaktadır. Süreç içerinde yeni sorunlarla problemin açmazları artmaktadır. Sayıları 3 milyona yaklaşan ve yarısından fazlasını kadınların ve çocukların oluşturduğu Suriyeli sığınmacıların durumu sadece Türkiye'nin bir sorunu değil uluslararası boyutta küresel bir sorundur. Göç, kadın, mülteci, sığınmacı üzerine sorulan sorular gelecekte artarak devam edecektir. Bu göç olayı her göç olayında olduğu gibi mutlaka geriye göçü de barındırsa içerisinde kalıcı göçü de barındıracağı için uzun dönemde toplumsal, kültürel, siyasal ve ekonomik çözümler ele alınıp gerekli düzenlemelerin ulusal ve uluslararası düzeyde yapılması şarttır.

\section{Kaynakça}

Bal, H. (2011). Kent Sosyolojisi. Isparta: Fakülte kitapevi.

Bauman, Z. (2003). Yasa Koyucular ile Yorumcular. (K. Atakay, çev.) İstanbul: Metis Yayınc1lik.

Bauman, Z. (2015). Bireyselleşmiş Toplum. (Y. Alagon, çev.) İstanbul: Ayrıntı Yayınları, 3. Bask1.

Bauman, Z. (2000). Postmodernlik ve Hoşnutsuzlukları. (İ. Türkmen, çev.) İstanbul: Ayrıntı Yayınlar1.

Bayhan, V. (1997). Türkiye’de İç Göçler ve Anomik Kentleşme[Bildiri]. II. Ulusal Sosyoloji Kongresi: Toplum ve Göç, 20- 21- 22 Kasım 1996 Mersin, Ankara: Devlet İstatistik Enstitüsü Yayınları.

Bourdieu, P. (2015a). Ayrım, Beğeni Yargısının Toplumsal Eleştirisi. (D. Fırat ve G. Berkkurt, çev.) Ankara: Heratik Yayınları, 2015a.

Bourdieu, P. (2015b). Eril Tahakküm. (B. Yılmaz, çev.) İstanbul: Bağlam Yayıncılık, 2. Baskı.

Bourdieu, P. \& Chartier, R. (2014). Sosyolog ve Tarihçi. (Z. Karaca, çev. ) İstanbul: Açllım Kitap.

Bourdieu, P. \& Passeron, J.(2014). Varisler Öğrencilerve Kültür. (L. Ünsaldı ve A. Sümer,çev.) Ankara: Heretik Yayıncilik.

Bourdieu, P. \& Passeron, J.(2015). Yeniden Üretim Eğitim Sistemine İlişkin Bir Teorinin İlke- 
leri. (L. Ünsaldı, Ö. Akkaya ve A. Sümer,çev.) Ankara: Heretik Yayıncılık.

Bourdieu, P. \& Wacquant, L. (2014). Düşünümsel Bir Antropoloji İçin Cevaplar. (N. Ökten, çev.) İstanbul: İletişim Yayınları.

Bourdieu, P. (2015c). Bourdieu ve Tarihsel Analiz. (P. S. Gorski, der. Ö. Akkaya, çev.) Ankara: Heretik Yayınları.

Castles, S. , Hass, H. , Miller, M.J. (2013). The Age of Migration, Fifth Edition, International Population Movements in the Modern World. Palgrave Macmillan, December. UK.

Durugönül, E. (1997). Sosyal Değişme, Göç ve Sosyal Hareketler[Bildiri]. II. Ulusal Sosyoloji Kongresi: Toplum ve Göç, 20- 21- 22 Kasım 1996 Mersin, Ankara: Devlet İstatistik Enstitüsü Yayınları.

Emirbayer, M.(1997). Manifesto for a Relational Sociology. The American Journal of Socio$\log y$, Vol. 103, No.2.

Giddens, A. (2008). Sosyoloji. (C. Gürsel, haz.) İstanbul: Kırmızı Yayınları.

Işık, O.\& Pınarcıŏlu, M.(2015). Nöbetleşe Yoksulluk: Sultanbeyli Örneği, 10.Baskı, İstanbul: İletişim Yayınları.

Jourdain, A. \& NAULIN, S. (2016). Pierre Bourdieu’nün Kuramı ve Sosyolojik Kullanımları. (Ö. Elitez, çev.). İstanbul: İletişim Yayınları.

Lefebvre, H. (2010). Modern Dünyada Gündelik Hayat, ( I. Gürbüz, çev.) Metis Yayınları, 2010, s. 11.

Levinas, E. (2003). Sonsuza Tanıklı. (Emmanuel Levinas'tan Seçme Yazılar). (Z. Direk ve E. Gökyaran, haz.). İstanbul: Metis Yayınları.

Levinas, E. (2011). Tanrı, Ölüm ve Zaman. (I. Ergüden, çev.) Ankara: Dost Kitapevi Yayınlar1.

Powell, C. ve Depelteau, F. (2015). İlişkisel Sosyoloji Ontolojik ve Teorik Yönelimler. ( Ö. Akkaya, çev. A.Esgin ve G. Çeğin, haz.) Ankara: Phoenix Yayınları.

Swartz, D. (2013). Kültür ve İktidar Pierre Bourdieu'nün Sosyolojisi. (E.Şen, çev.) İstanbul: İletişim Yayınları.

T.C. İçişleri Bakanlı̆̆ı Göç İdaresi Genel Müdürlüğ̈̈ Yayınları, Yayın No:4. Aralık 2013. Ankara.

Tatlıcan, Ü. ve Çeğin, G. (2010). Bourdieu ve Giddens: Habitus veya Yapının İkiliği. Ocak ve Zanaat Pierre Bourdieu Derlemesi. İstanbul: İletişim Yayıncllık.

Thorpe, C., Yuill, C., Hobbs, M., Todd, M., Tomley, S. ve Weeks, M. (2015). Sosyoloji Kitabı. (T. Göbekçiyan, çev.) İstanbul: Alfa Yayınları.

Ünal, A. (2010). Rahatsız Eden Bir Adamın Bilimi: Sosyoloji. Ocak ve Zanaat Pierre Bourdieu Derlemesi.

(G. Çeğin, E. Göker, A. Arlı ve Ü. Tatlıcan, der.), İstanbul: İletişim Yayıncılık. 